\title{
ТСM \\ COVID-19 in Brazil: an analysis about the consumption of information on social networks
}

\section{Luisa Massarani, Igor Waltz and Tatiane Leal}

\begin{abstract}
In this article, we analysed the 100 most engaging contents about COVID-19 on social networks in Brazil, in March 2020, when the disease officially arrived in the country. Within the infodemic context, we analysed the accuracy of the information and the reliability of the websites that guided the debate. Our results show that misinformation/disinformation accounted for $13.5 \%$ of the sample and that their average engagement was greater than the one for the information that could be verified in other sources and in accordance with scientific evidence. We also found that professional websites, especially journalistic ones, predominate among sources. The results point to the need to combine science communication strategies with network communication dynamics.
\end{abstract}

Keywords

Health communication; Science and media; Science communication in the developing world

DOI

https://doi.org/10.22323/2.19070207

Submitted: 23rd June 2020

Accepted: 29th September 2020

Published: 14th December 2020

Context

The outbreak of COVID-19 triggered an international crisis with social, political, economic and scientific implications. In Brazil, the outbreak of the new disease worsened the historical problems of unequal access to public health, drinking water and basic sanitation, besides worsening ongoing socio-political tensions. Although there is evidence that the new coronavirus has been circulating in Brazil since February [Candido et al., 2020], local transmission in the country and the first deaths were confirmed in March. During this time, national and local governments across the entire country suspended school classes and restricted business activities, transportation and the circulation of people, while President Jair Bolsonaro adopted a negative and critical attitude towards social isolation measures. These tensions contributed to the worsening of the crisis in Brazil, which became one of the global epicentres of COVID-19.

In view of this critical situation, communication plays a key role in fighting the epidemic. Social networks expand the circulation and increase the use of scientific 
information, becoming a privileged space for information on measures of containment, prevention, symptoms and treatments. However, the COVID-19 pandemic has been accompanied by large-scale production and circulation of information [World Health Organization, 2020]. The 'infodemic' overloads the public debate and hinders the identification of reliable sources, as the large volume makes it difficult for one to assess the accuracy of the information [Posetti and Bontcheva, 2020].

These factors significantly challenge science communication, especially in times of crisis. Investigating the contours of the debate about COVID-19 on social networks can support production strategies and the circulation of information about science and health. Thus, our objective in this paper is to carry out a critical analysis of the most shared and commented content about COVID-19 on social networks in Brazil, in March 2020, in order to find out to what extent the infodemic can influence this debate.

Theoretical foundation
The emergence of a public health crisis reinforces concerns about science communication strategies. Science communication concerns a series of actions organised to communicate scientific knowledge, methodologies, processes and scientific practices to a wide audience, including institutions, interest groups, policy makers and the lay public [Trench and Bucchi, 2010; Davies and Horst, 2016]. Science communication was for a long time tied to a "deficit model" based on the idea that specific scientific content should be communicated to those who did not know it [Massarani, 2012; Castelfranchi et al., 2013], which contributed to a "paternalistic" model of science communication [Bucchi, 2008]. However, this vision has been giving way to a model of co-production of knowledge based on civic participation in the construction of a shared agenda [Bucchi, 2008].

The idea of co-participation is particularly relevant in a context such as the current one, which requires a collective response to contain the coronavirus. Science communication offers the opportunity of interactions between citizens, governments and organisations to align scientific production with world understanding and decision-making [Kahan, Scheufele and Jamieson, 2017]. However, this objective faces a series of historical problems in Brazil, such as the reach of science communication among the population and the absence of systematic public policies for its development [Massarani and De Castro Moreira, 2016].

During an epidemic, science communication can be a fundamental instrument for health communication, spreading scientific knowledge related to this field. Health communication consists of the study, production and sharing of health information to different audiences, such as the general public, professionals in the field and policy makers [Schiavo, 2007]. It is a central element of public health, intended as a set of efforts by a society to guarantee health conditions for its population. Therefore, public health communication consists of the interdisciplinary development of scientific knowledge and strategic actions for the spreading and evaluation of health information that aim to contribute to public health in a relevant, accurate and accessible way [Bernhardt, 2004]. 
As in the debate about the limitations of the "deficit model" in science communication, studies in health communication highlight the importance of moving away from a medical model based on the vertical transmission of information and adopting an educational model instead, which values the perceptions and knowledge of the sectors of population with whom it seeks to establish a dialogue [Trench and Bucchi, 2010]. The aim is to promote the engagement of these groups in health promotion, reinforcing the importance of systematic, participatory and long-term communication [Schiavo, 2007].

In public health emergencies such as that of COVID-19 pandemic, the conceptual instruments of science and health communication should be combined with those of risk communication. The latter consists of communicating information about medical, environmental and social hazards, identifying the concerns of the affected social groups and mitigating the circulation of unreliable information, with the aim of minimising and managing the possible impacts on the population [Glik, 2007; World Health Organization, 2018]. In a public health crisis, these communication strategies contribute to preserve lives, since risk perception can stimulate proactive behaviors and engagement with the actions recommended by experts. For this reason, risk communication in times of crisis must be accurate, clear and credible [Glik, 2007].

However, crises present a number of conditions that facilitate disinformation. Their scenarios are characterised not only by high levels of risk and uncertainty, but also by a high level of stress among the population, conditions that facilitate an unstable communication environment, in which the increased demand for information may jeopardise the ability of the system to provide it accurately [Glik, 2007]. When it comes to an emerging disease, this scenario worsens, since the information conveyed by researchers, physicians and authorities may be constantly changing as the knowledge of the disease improves, and this is reflected in the coverage carried out by the media. Therefore, risk communication in a health emergency faces the challenge of alerting the population without spreading panic amid uncertain events [Silva Medeiros and Massarani, 2011].

In the case of the COVID-19 pandemic, social distancing imposed the need to reorganise human relations by using communication technologies. The ever more rapid spreading of information, including rumors and gossips, has always followed epidemic outbreaks [World Health Organization, 2018; Zarocostas, 2020], but the current pandemic has significantly increased the concerns about infodemic. Compared to previous outbreaks such as SARS, MERS and Zika, social media today significantly amplify both false information about the disease and ultranationalist, xenophobic and racist content [Hao and Basu, 2020].

By social media we refer to tools that are technologically and ideologically designed based on the participatory model of web 2.0, enabling users to produce, use and share content with each other, creating social networks in these spaces [Kaplan and Haenlein, 2010]. Currently, social media are a privileged space for the circulation of information about health and science and technology (S\&T), offering both benefits and risks among its uses. Among the positive aspects, social media facilitate intercommunication between patients, professionals, researchers and the general public, making the production of content more democratic. In the field of public health communication, these media have also been successfully used in 
health promotion campaigns, reaching a large audience effectively. In addition, their multimedia formats can be explored to promote accessibility and to reach audiences with different levels of literacy [Chou et al., 2009; Moorhead et al., 2013].

The analysis of data produced by social media users can also be a valuable tool in epidemic contexts. Studies on the circulation of content on Facebook and Twitter during the H1N1 pandemic in 2009 [Chew and Eysenbach, 2010; Ahmed et al., 2019] and the Zika epidemic in 2015 and 2016 [Hagen et al., 2018; Sharma et al., 2017] demonstrate that scientific research about conversations on social media can provide clues to understand public attitudes and perceptions about these diseases and their crisis contexts. This recognition of the Internet as a potential data source encouraged the creation of the field of digital epidemiology, which uses digital data to understand patterns and dynamics of health and disease in the population [Salathé, 2018]. Tweets and posts can even be monitored to detect early disease outbreaks in certain locations [Joshi et al., 2020].

Regarding the risks posed by social media, it is worth highlighting concerns about the quality and reliability of content. The participatory nature of the networks allows spaces in which incorrect, sensationalist and distorted health information can circulate [Chou et al., 2009; Moorhead et al., 2013]. In addition, the re-circulation of information without its full comprehension is a common aspect, especially when the title confirms the beliefs and previous opinions of the users [Recuero, Zago and Soares, 2019]. The plurality of content circulating on social media also brings the problem of unidentified authorship or sources, which worsens the existing disinformation. Therefore, although social media have a significant potential for health communication, it is necessary to investigate the quality and reliability of shared information [Chou et al., 2009; Moorhead et al., 2013].

In this way, the shock and collective fear caused by the new virus, combined with the ubiquity of social networks, constitute a fertile ground for communication overload [Fuchs, 2020]. The infodemic constitutes a source of concern because it can influence people's behavior and jeopardise the efficiency of containment measures [Gallotti et al., 2020; Cinelli et al., 2020]. This "informational disorder" [Wardle and Derakhshan, 2017] includes a series of damaging speeches such as leaks, hate speech, and deliberately false information, created and shared to harm people and social groups.

In this sense, Wardle and Derakhshan [2017] suggest the use of misinformation and disinformation classifications to refer to this informational pollution. Misinformation indicates distorted, ambiguous or unclarified information from misinterpretation or false connections. Disinformation, on the other hand, refers to intentionally false information, including content out of context, impostor content (falsely attributed to the news media or a personality), manipulated content (genuine information, such as photos and videos, edited to deceive) or completely fabricated content. In this sense, the authors state that the opposite term to disinformation is 'verifiable information', which is information capable of being examined, compared, and contrasted with other sources identified as reliable.

More than establishing a 'truth', verification allows one to point out whether a message is accurate or not in front of other data and information. Although the 
verification of information is not a recent practice, the amount of information conveyed by digital networks turned this activity into a specific tool - 'fact-checking' - a method used to check the accuracy of public speeches, shared messages on the Internet, commercial advertisements and political propaganda, etc. In addition to a "journalistic genre" [Graves, Nyhan and Reifler, 2016], 'fact-checking' has also been adopted outside the field of journalism by academic researchers, public policy experts and activists linked to non-governmental organisations [Graves and Cherubini, 2016]. In the case of content related to science and health, the 'fact-checking' method necessarily involves verifying whether the information the content conveys is in accordance with the evidence accepted by the scientific and medical community, by consulting academic articles in the area and guidelines issued by health authorities [Sommariva et al., 2018].

In addition to verifying the content of messages, the identification of the information sources can help understand the communication environment affected by infodemic. Initiatives that used social networks for science communication during the pandemic in China confirm that these environments have the potential for the rapid and effective spreading of science-based knowledge and should be considered as important tools to optimise the fight against the crisis globally. However, for this potential to materialise, it is crucial to ensure that social media users have access to quality information issued by verifiable sources [Chan et al., 2020].

Within the context of the COVID-19 infodemic, several studies have attempted to analyse and classify the different false or misleading content circulating on social networks. According to Salaverría et al. [2020], most of the fake news spread in Spain concerns the origin of the coronavirus, its lethality and permanence in the environment. Unfounded treatment and prevention measures such as the use of drugs without proven efficacy, home-made solutions or dietary supplements also stand out. Brennen et al. [2020] highlight the presence of false and misleading claims about the actions of health authorities and the blaming of ethnic groups for the spread of the virus in the U.K. In turn, the global-scope study by Pulido et al. [2020] points out that messages with fake content related to COVID-19 on Twitter are more tweeted than messages containing information based on scientific evidence or on 'fact-checking', even if they are less re-tweeted and generate less engagement.

These theoretical and methodological contributions reinforce the importance of carrying out research in social media about the COVID-19 pandemic, especially in the Brazilian context. Since the onset of the pandemic, federal, state and local authorities have disagreed on how to contain the virus and reduce its social impact. On March 24, President Bolsonaro broadcast one of the first national statements on COVID-19, criticising the lockdown and defending the resumption of work activities. Bolsonaro had already taken actions contrary to social distancing, when calling and participating in marches in favour of his government. In addition, in the middle of the crisis between April and May, the lead of the Ministry of Health was changed twice, due to the disagreement between the President and the post holders [The Lancet, 2020]. This led to a General of the armed forces with no prior experience in the health field being put in charge of this Ministry [Barberia and Gómez, 2020]. These political-ideological tensions contributed to the worsening of 
the crisis in Brazil. Between June and August 2020, Brazil was the second country in the world with the highest number of deaths from COVID-19 (India has overtaken the position in September). In October, Brazil reached 150 thousand deaths from the disease. ${ }^{1}$

In Brazil, where $74 \%$ of the population over the age of 10 use the internet [Instituto Brasileiro de Geografia e Estatística, 2018], it is crucially important to analyse how the information about COVID-19 circulates and is consumed. At present, social media are a source of news for $67 \%$ of Brazilians, followed by television, with $66 \%$. Among the most used news social media, Facebook stands out with 54\%, followed by Whatsapp (48\%), YouTube (45\%), Instagram (30\%) and Twitter (17\%) [Newman et al., 2020]. This data, therefore, points out the importance of social networks when it comes to how information is used in Brazil. Therefore, investigating the contours of the discussions about COVID-19 on social networks can support production strategies and the circulation of information in science and health.

The aim of this article is to analyse the circulation of content about COVID-19 on social networks in Brazil in March 2020 - the month that marked the beginning of the pandemic in the country - by investigating the reliability of this information in a context of infodemic. For this reason, we started from exploring the engagement of social network users in Brazil, based on metrics such as shares, comments and reactions. Engagement can be understood as the subjects' social and emotional attachment to certain ideas, where the communicational dimension plays a key role [Bastos, 2020]. In social media, engagement is measured based on the interaction of users with a given post, on the basis of actions such as commenting, liking and sharing. Although the act of linking to ideas is not limited to these actions, interaction on social networks is an important indicator of user engagement with certain contents [Smith and Gallicano, 2015].

It is important to note that the forms of interactions vary between social networks - comments, shares, likes, reactions, etc. On these platforms, the large volume of information can dissipate the attention of interacting users, and much of the content is not even read or absorbed. Engagement demonstrates that content has drawn the attention to the point of promoting active interaction on the part of the user. Content with more engagement also receives, exponentially, more visibility, as networks tend to show posts with higher engagement more frequently to other users.

Within the context of this research, engagement is important because (1) it indicates the content that drew the most attention, which provides important data to understand the public's perception about COVID-19; (2) it allows to measure the content with greater visibility and popularity on social networks, making it possible to scan the public debate on these platforms. Therefore, although we recognise that social network protocols, in a way, influence user participation, investigating interactions around the discussion on COVID-19 can provide clues about audience involvement and privileged frameworks, besides allowing one to assess the presence of disinformation among the most popular content concerning COVID-19 on social networks.

\footnotetext{
${ }^{1}$ See more at https:/ / coronavirus.jhu.edu/map.html. Accessed: 16 October 2020.
} 
To this end, the aim was to 1) identify the content about COVID-19 that had the most shares, comments, likes and reactions on social networks in the analysed period; 2) assess the presence of disinformation within this content; 3 ) identify and assess the reliability of the sources that convey this information. This analysis may provide clues for the formulation of public communication strategies for S\&T and health aimed at facing the pandemic, especially in containing the spread of disinformation.

Methodology

The research presented two methodological steps: the collection of empirical data and the analysis of the results. In the first stage, we used BuzzSumo, ${ }^{2}$ a monitoring tool that quantifies the engagement generated by social media content, taking shares, comments and likes as quantifiable metrics. BuzzSumo regards as engagement the sum of shares, comments, likes and reactions that a link obtained on Facebook, Twitter, Reddit and Pinterest and analyses only public posts in each one. By using filters such as 'language', 'analysis period' and 'keywords', BuzzSumo allows to identify the content that generated the greatest engagement on these social networks.

BuzzSumo has been used in scientific research that investigates the circulation of disinformation on social media [Allcott, Gentzkow and Yu, 2019; Allcott and Gentzkow, 2017], including the health field [Shoureshi et al., 2020; Alsyouf et al., 2019; Sommariva et al., 2018; Waszak, Kasprzycka-Waszak and Kubanek, 2018]. These authors point out that the tool allows identifying the content with the greatest engagement, providing quantifiable metrics in a user-friendly interface, which enables the investigation of social networks, marked by the circulation of a huge, dynamic and varied volume of data [Hine, 2015]. We chose this tool on the basis of these criteria. BuzzSumo is a commercial tool, but it has a free testing tool that allows us to collect up to one hundred 'links' with the highest engagement level on the same topic. For this study, we had to use the free version of this tool, since we did not have the resources to use the full-price version. However, we would like to emphasise that the free version allows the consolidation of a robust corpus. In addition, we believe that this paper may inspire other studies carried out by researchers who do not have the financial resources to support their studies, such as young researchers or those from developing countries.

Like other tools, BuzzSumo has some technical limitations, such as collecting a maximum of one hundred links and not being able to compare and contrast the engagement of different social networks in detail. However, we consider that the data generated is sufficient for the research objectives.

From BuzzSumo, we collected 100 topics with the keywords 'COVID-19' and 'coronavirus' that generated the highest engagement on Facebook, Twitter, Reddit and Pinterest between the 1st and the 31st of March, 2020. The sample includes one hundred links because this is the maximum number allowed by the free version of this tool. We used the Portuguese language as a filter. Among the one hundred links collected, 99 were published by Brazilian websites and only one from Portugal, which was therefore excluded from our sample. After excluding this link and two others that were repeated, the final sample consisted of 97 links.

\footnotetext{
${ }^{2}$ Available at https:/ / buzzsumo.com/. Accessed: 27 May 2020.
} 
For each of the 97 links we considered the data that BuzzSumo refers to as 'total engagement', or the sum of the numbers of 'Facebook Engagement' (shares, comments, likes and reactions), 'Twitter Shares' (shares), 'Reddit Engagements' (shares and comments) and 'Pinterest Shares' (shares) for each of them. One of the tool limitations is that it is impossible to compare and contrast these social networks [Allcott, Gentzkow and Yu, 2019], because for Twitter and Pinterest it only considers shares and for Reddit and Facebook it also includes comments and, for the latter one, likes and reactions too. However, as the comparison between different social networks does not fall within the purpose of this study, the quantification of total engagement is satisfactory for our aim of analysing the accuracy of the most popular content on social media.

It is important to note that we did not disregard the role of robots, paid advertisements and network algorithms in promoting the engagement of certain contents. However, we considered the network's environment regarding its complex mediations between human and non-human agents [Latour, 2005]. In this way, it is not a matter of seeing the sample gathered by BuzzSumo as a reflection of real public opinion, but of understanding that public opinion is necessarily built from social and technological mediations.

In the second methodological stage, we use mixed methods to carry out a quali-quantitative analysis of the material in four steps. In step 1, we applied the 'fact-checking' method qualitatively to classify the content found according to its 'accuracy'. The accuracy of these contents was determined by comparing it with information from scientific papers, official sources and other journalistic articles. For this stage, we adopted the classification proposed by Wardle and Derakhshan [2017], sorted in Table 1.

Table 1. Classification of mis/disinformation. Source: The authors, based on Wardle and Derakhshan [2017].

\begin{tabular}{|ll|}
\hline Verified content & $\begin{array}{l}\text { Information that can be verified based on scientific and/or } \\
\text { journalistic official sources }\end{array}$ \\
\hline Misleading content & The misleading use of information to frame an issue or a person \\
\hline Manipulated content & $\begin{array}{l}\text { Genuine content that is edited or manipulated in order to de- } \\
\text { ceive }\end{array}$ \\
\hline Fabricated content & Content that is $100 \%$ false, created to deceive or harm \\
\hline False context & $\begin{array}{l}\text { Genuine content shared together with false context information } \\
\text { (e.g. location, date, etc.) }\end{array}$ \\
\hline False connection & Titles, headlines and visual elements contradict the content \\
\hline Parody or satire & Humouristic intention, which may generate confusion \\
\hline
\end{tabular}

Still in the first step, during our analysis, there was the need to include the category 'Non-verifiable content', for information that cannot be compared, such as personal opinions and public surveys.

In step 2, we quantitatively analysed the engagement of verifiable information, 'misinformation' and 'disinformation' from the data gathered by BuzzSumo, in order to assess the prominence of the content in the public debate. In step 3, we identified the websites responsible of each link, with the intention to assess the reliability of the information sources that guided the debate on the topic. We first 
listed all the media outlets responsible for the links collected in the sample. Then, we divided them into 'professional' and 'non-professional'. Inspired by research that determined criteria for assessing the reliability of health information sources [Mendonça and Neto, 2015; Silva, Luce and Silva Filho, 2017], we chose the following criteria to consider a website as 'professional': defined vision and editorial policy; indication of physical address; identification of the editorial team and the authors of the texts; and citing the sources of the information. We evaluated the websites and their social media pages, and those that did not provide this information were considered 'non-professional'. This classification was intended to provide clues for assessing the reliability of media outlets that gained more visibility in the public debate on COVID-19.

Results

The 97 links generated a total of approximately 52.5 million interactions, including likes, comments and reactions, on the social networks analysed in this research. Engagement ranged from about 1.4 million interactions for the most popular link to about 309.5 thousand for the least popular link in the corpus. Table 2 shows the quantified engagement in each of the four networks analysed.

Table 2. Numbers of engagement from 100 links about COVID-19 gathered by BuzzSumo from each social network analysed. Source: The authors, based on the data from BuzzSumo.

\begin{tabular}{|lr|}
\hline \multicolumn{1}{|c}{ Social Network } & Engagement \\
\hline Facebook Engagement & $52,247,900$ \\
Twitter Shares & 201,108 \\
Reddit Engagement & 6,100 \\
Pinterest Shares & 29 \\
Total Engagement & $52,455,137$ \\
\hline
\end{tabular}

In terms of 'accuracy', there was a predominance of links with verified information about COVID-19 (82.4\%). On the other hand, 'mis/disinformation' accounted for $13.5 \%$ of the analysed links, classified as false connection $(5.2 \%)$, misleading content $(4.1 \%)$ and fabricated content $(4.1 \%)$. In our sample, no parodies, satires, manipulated content or false context were identified. Texts disclosing individual opinions or polls were classified as 'non-verifiable content' (4.1\%) (See Figure 1).

However, although there was a greater volume of verified content, the quantitative analysis revealed that the content classified as 'mis/disinformation' had a higher engagement average in the analysed period. While verified content had an average of 534,500 interactions, including likes, shares and comments, content with incorrect or distorted information had 602,800 interactions (See Table 3).

Table 3. Average engagement of content about COVID-19 gathered by BuzzSumo. Source: The authors, based on the data from BuzzSumo.

\begin{tabular}{|ll|}
\hline Total average engagement & 540,447 \\
Average engagement for verified content & 534,524 \\
Average engagement for mis/disinformation & 620,800 \\
Average engagement for non-verifiable content & 456,275 \\
\hline
\end{tabular}

We found 45 different websites among those responsible for the 97 analysed 'links', but four of them - UOL, O Globo, R7 and G1 news portals - account for $48.5 \%$ of 


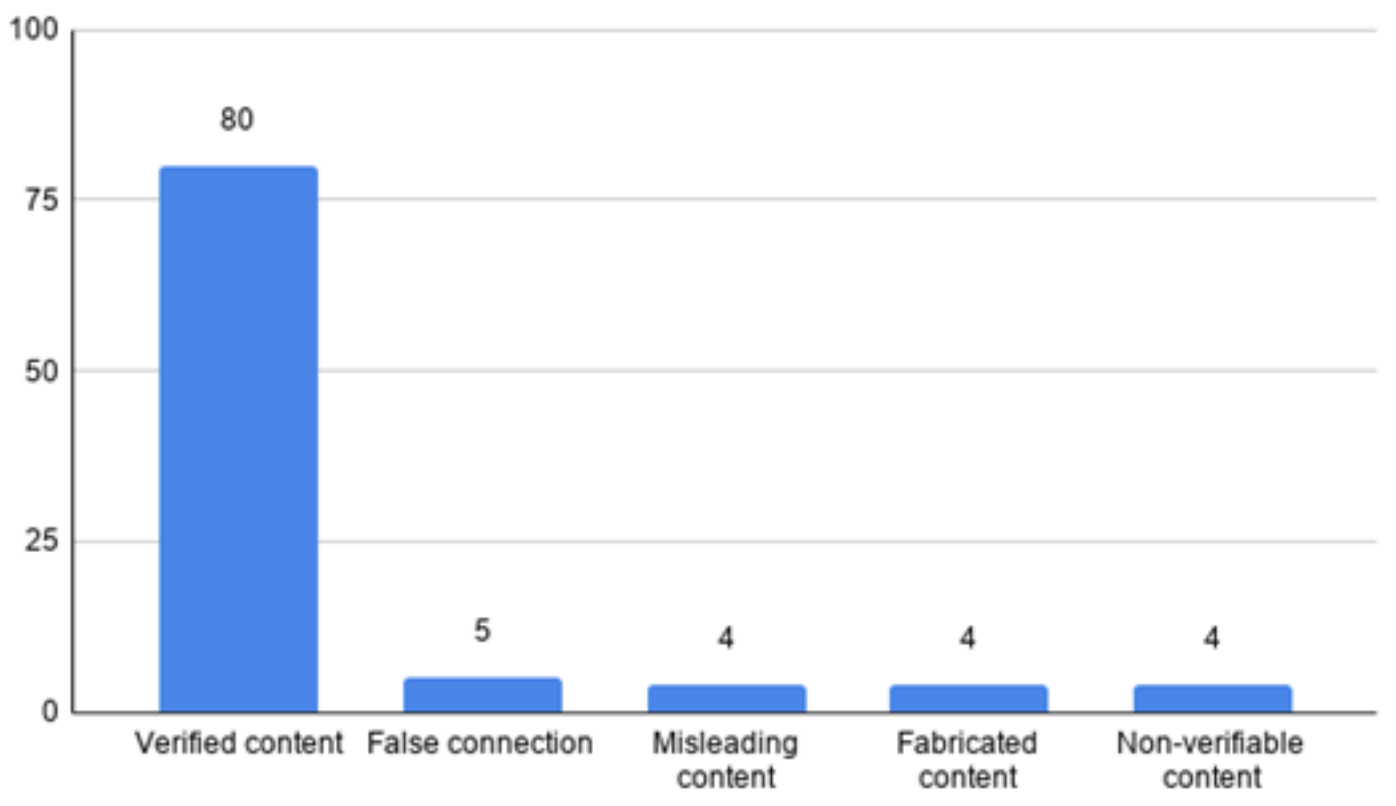

Figure 1. Classification of content about COVID-19 in terms of its accuracy. Source: The authors, based on the data from BuzzSumo.

the sample links. These journalistic websites belong to large Brazilian media corporations, which also own newspapers, radio stations and TV channels. As for the 'types of websites', 35 were identified as 'professional' $(77.8 \%$ of the total sample) and $10(22.2 \%)$ as 'non-professional' (See Figure 2).

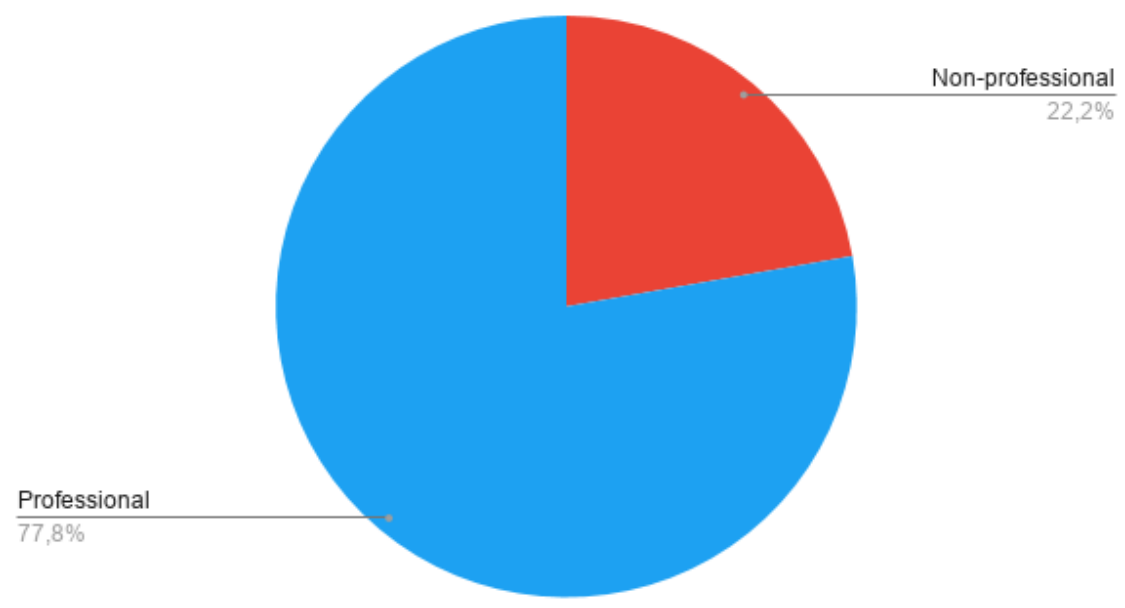

Figure 2. Classification of the websites in the sample. Source: The authors, based on the data from BuzzSumo.

Within the 'professional' category, we identified 30 'journalistic' websites and portals $(85.7 \%)$, one 'Variety and Entertainment' website (2,9\%), one 'Institutional' medium $(2,9 \%)$, one media outlet specialised in 'Sports' $(2,9 \%)$, one in 'Economics and Business' (2,9\%) and one in the 'Legal' field (2.9\%) (See Figure 3). 


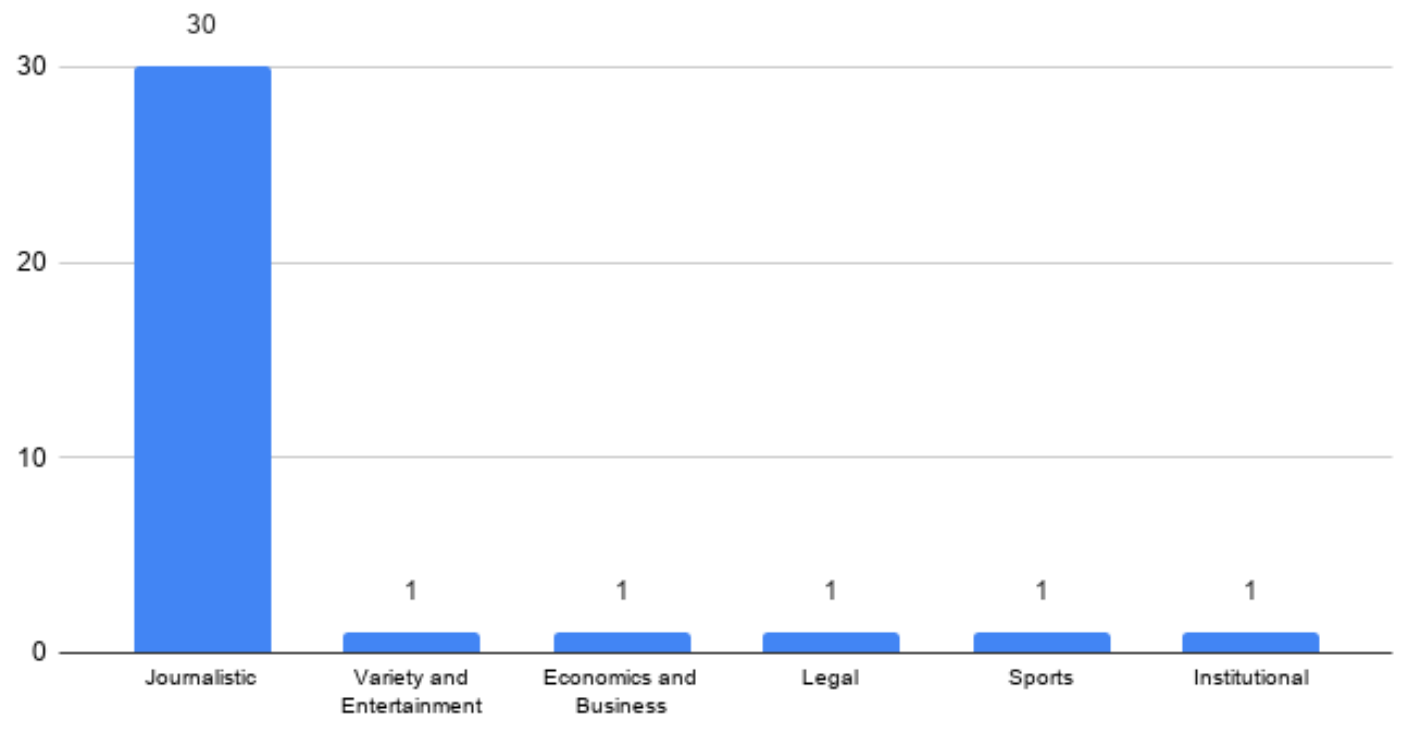

Figure 3. Classification of the 'professional' websites in the sample. Source: The authors, based on the data from BuzzSumo.

networks. Regarding the quantitative analysis of total engagement, interactions were mainly concentrated on Facebook and Twitter, which establish themselves as key social networks in the evaluation of public debate on social networks in Brazil. Although it is not possible to directly compare the two networks, since BuzzSumo counts only shares on Twitter (201.1 thousand) and shares, comments and reactions on Facebook (52.2 million), the huge result of engagement in the latter confirms the importance of this network for the field of science and health communication, as already measured by research on the use of social media in Brazil. Among the four social networks analysed, Facebook is the main platform users choose to share and consume information about the pandemic.

Therefore, in Brazil S\&T communication strategies about COVID-19 in social media may identify Facebook as the main network that can guide their implementation. The social networks Reddit and Pinterest had a low presence among the results, which can demonstrate that their use in Brazil, at least for the field of health and science communication, is still at its early stage.

There is a predominance of verified information (82.4\%), which is information that can be checked in other sources and in accordance with scientific evidence. Among this content, there is a predominance of information on the political scenario, with emphasis on the figure of President Jair Bolsonaro and economic measures mitigating the social impact of the pandemic. To a lesser extent, there were also articles with data on the spread of the disease, individual protection measures and personal stories from health professionals and socially vulnerable people.

However, $13.5 \%$ of the content identified as 'mis/disinformation' obtained, on average, higher engagement, which points to the rapid dissemination and significant visibility for this type of content in the network environment. Among mis/disinformation, 'False connections' (5.2\%) prevail: visual elements, such as headlines and images, contradict the textual content. These elements serve to retain the readers' attention. However, in the current regime of attention in digital 
networks, content is often recirculated without being read in full, which contributes to disinformation.

Examples of 'False Connection' include news such as "Jornal Marca diz que Cristiano Ronaldo transformará seus hotéis em Portugal em hospitais para pacientes do COVID-19" (Globo Esporte) ${ }^{3}$ [The news portal Marca says Cristiano Ronaldo will transform his hotels in Portugal into hospitals for COVID-19 patients]. When reading the content of this article, it is possible to know that the Portuguese sportsman did not take this decision, although its title does not suggest it. Likewise, the title of the article "EUA abre ação contra China pela pandemia do coronavírus" (Diário do Pará) ${ }^{4}$ [U.S. takes action against China over coronavirus pandemic] suggests that there was a legal action by the U.S. government, when the body of the article clarifies that it is a collective action brought by a law firm.

There are false connections also about the treatment of COVID-19. The news "Quatro pacientes de UTI tiveram alta em SP com uso de hidroxicloroquina" (UOL) ${ }^{5}$ [Four ICU patients were discharged in São Paulo using hydroxychloroquine] may suggest the action of the drug against COVID-19, but the text points out that "there is no proof of the cause and effect of the use of hydroxychloroquine. In other words, it is not possible to guarantee that the patients were cured thanks to the medication". Although one cannot say that they are intentional, the inconsistencies present in these articles can confuse readers, generate errors of interpretation and contribute to information pollution.

'Misleading content' (4.1\%) also stands out when there is an incorrect use of information to frame an issue or an individual. This type of content may include, for example, selecting and/or omitting data, quotes and statistics. For example, the article "Coronavirus: sem turistas, tartarugas retornam em massa para fazer seus ninhos nas costas indianas" (Revista Pazes) [Coronavirus: without tourists, turtles return en masse to breed on the Indian coasts] discusses the environmental impact of the measures to contain the coronavirus. However, there is no proven relation between social isolation and the appearance of turtles on a beach in eastern India, something that had already occurred seven years earlier. Besides, the event is reported to have taken place on March 22, three days before the lockdown was enacted in the Asian country.

That is also the case with the article "Orgasmos podem fortalecer sistema imunologico para prevenir coronavirus ${ }^{7}$ [Orgasms can strengthen the immune system to prevent coronavirus]. This is about a 2004 study carried out exclusively with men, pointing out that orgasms can influence the response of the immune system. The study was published long before the coronavirus outbreak and the correlation between the

\footnotetext{
${ }^{3}$ Available at https:/ / globoesporte.globo.com/futebol/futebol-internacional/noticia / cristiano-ronaldo-transformara-seus-hoteis-em-portugal-em-hospitais-para-pacientes-do-covid-19diz-marca.ghtml. Accessed: 5 April 2020.

${ }^{4}$ Available at https: / / www.diarioonline.com.br/noticias / mundo-noticias /579000/eua-abre-acaocontra-china-pela-pandemia-do-coronavirus. Accessed: 5 April 2020.

${ }^{5}$ Available at https:/ / www.uol.com.br/vivabem/noticias/redacao/2020/03/26/quatropacientes-de-uti-tiveram-alta-em-sp-com-uso-de-hidroxicloroquina.htm. Accessed: 15 April 2020.

${ }^{6}$ Available at https:/ / www.revistapazes.com/coronavirus-sem-turistas-tartarugas-retornam-emmassa-para-fazer-seus-ninhos-nas-costas-indianas/. Accessed: 5 April 2020.

${ }^{7}$ Available at https:/ / www.diariodocentrodomundo.com.br/essencial/orgasmos-podemfortalecer-sistema-imunologico-para-prevenir-coronavirus/. Accessed: 5 April 2020.
} 
two is hasty. In turn, the news "Itália já prevê deixar pacientes de COVID-19 com mais de 80 morrerem $^{\prime \prime}$ (R7) [Italy already plans to let COVID-19 patients over 80 die] reflects an interpretation error in several newspapers around the world: a document from the Italian Society of Anesthesia and Intensive Care (Siaarti) intended to discuss medical ethics in hypothetical scenarios, with no intention of establishing tangible guidelines.

Similarly, the only content produced by an institutional medium was identified as 'misleading content': the official channel of the Presidency of the Republic on YouTube. In his March 24 statement, President Jair Bolsonaro criticises isolation measures taken by state and local authorities and accuses the press of causing "hysteria". ${ }^{9}$ The video contains distorted information, such as that COVID-19 is a mere cold, the tropical climate would make it difficult for the virus to spread, and that only people over 60 should isolate themselves. Although there is a scientific consensus that the elderly fall into the risk group, younger people can spread the disease, even when asymptomatic or with mild symptoms. Therefore, there is the need for social isolation in all age groups. In addition, there are studies that indicate that SARS-COV -2 is sensitive to higher temperatures, however the hot climate would not prevent it, but would delay its spreading [Araujo and Naimi, 2020].

There are also cases of 'Fabricated content', usually linked to certain political views and personal beliefs. The article "Coronavirus: Sem nenhum caso, Cuba desenvolve vacina e pode salvar planeta" (Revista Fórum) ${ }^{10}$ [Coronavirus: Without any case, Cuba develops a vaccine and can save the planet] suggests that the socialist country had already produced a vaccine against the coronavirus in March, which did not happen. In addition, contrary to what the text states, the Caribbean country had already registered the first cases of COVID-19 at the time of publication.

However, it is not possible to categorically point out that all of these articles are intentionally false. On the other hand, the concern with disinformation can be inferred from the amount of texts denying false information, especially when disseminated by the government. Articles such as "Bolsonaro insiste que crise do coronavirus é histeria" (El Pais) ${ }^{11}$ [Bolsonaro insists that the coronavirus crisis is hysteria], "Bolsonaro diz que coronavírus não passará em lotéricas porque vidro é blindado" $(\mathrm{O} \text { Globo })^{12}$ [Bolsonaro says that the coronavirus will not pass in lottery shops because glass is armored], or "Bolsonaro questiona número de mortos por COVID-19 e fala em fraude para 'uso politico'" (O Globo $)^{13}$ [Bolsonaro questions the number of deaths by COVID-19 and speaks about fraud for 'political use'], highlight inconsistencies in the President's speech and denounce his irreducible stance in relation to isolation measures.

In addition, it is necessary to highlight the presence of 'Non-verifiable content': comments, personal and collective opinions that therefore cannot be verified. That

\footnotetext{
${ }^{8}$ Available at https:/ / noticias.r7.com/internacional/italia-ja-preve-deixar-pacientes-de-covid-19com-mais-de-80-morrerem-17032020. Accessed: 5 April 2020.

${ }^{9}$ Available at https:/ /www.youtube.com/watch?v=Vl_DYb-XaAE. Accessed: 2 April 2020.

${ }^{10}$ Available at https: / / revistaforum.com.br/noticias/coronavirus-sem-nenhum-caso-cubadesenvolve-vacina-e-pode-salvar-planeta/. Accessed: 5 April 2020.

${ }^{11}$ Available at https: / / brasil.elpais.com/brasil/2020-03-17/bolsonaro-insiste-que-crise-docoronavirus-e-histeria-e-ex-aliados-sugerem-seu-afastamento.html. Accessed: 15 April 2020.

${ }^{12}$ Available at https: / / oglobo.globo.com/brasil/bolsonaro-diz-que-coronavirus-nao-passara-emlotericas-porque-vidro-blindado-1-24331311. Accessed:15 April 2020.

${ }^{13}$ Available at https: / / oglobo.globo.com/brasil/sem-provas-bolsonaro-questiona-numero-demortos-por-COVID-19-fala-em-fraude-para-uso-politico-24333952. Accessed: 15 April 2020.
} 
is the case of the polls published by the website Plantão ao Vivo, which asks readers "Você acha que o Lula se sairia melhor que Bolsonaro no combate ao coronavírus no Brasil?"14 [Do you think Lula would do better than Bolsonaro in fighting the coronavirus in Brazil?] and "Você é a favor da libertação de presos para evitar epidemia de coronavirus nas prisões?"15 [Are you in favour of the release of prisoners to prevent the coronavirus epidemic in prisons?]. The text written by the UOL columnist Tales Faria was also classified as 'non-verifiable'. In the article "Bolsonaro está convencido de que coronavirus é um plano do governo chinês" ${ }^{16}$ [Bolsonaro is convinced that coronavirus is a Chinese government plan], the journalist states, based on an undisclosed source, that the Brazilian President would have spoken in his private inner circles saying that COVID-19 would be a Chinese conspiracy to harm the world economy. However, Bolsonaro never made such statements publicly, unlike one of his sons. Therefore, we considered it as information that is not yet verifiable.

We identified 45 websites, of which 35 were classified as 'professional' and 10 as 'non-professional'. In a context of rapid dissemination of disinformation and growing hostility against science and the press, the predominance of journalistic portals and websites (30) among those classified as 'professional' is important. Our previous research on public debate about scientific topics on social networks, such as vaccines [Massarani, Leal and Waltz, 2020], also pointed to a significant share of journalistic content among those with most interactions.

Authors such as Bueno [2009] recognise scientific journalism as an important element of science communication, playing a role that is more than informative, being also social, cultural and educational, by placing science and technology in a broader social context. This role becomes even more crucial, particularly in a scenario of political and health crisis and escalating disinformation. This becomes clear, for example, when we observe that almost half (48.5\%) of the most engaging content was produced by only four journalistic outlets, all connected to large Brazilian media corporations: UOL, from Grupo Folha; R7, from Grupo Record; and G1 and O Globo, both from Grupo Globo. This data highlights the power that the hegemonic media still hold in Brazil, guiding the conversations on the networks and building a symbolic capital of "reliability".

However, it is also necessary to take into account the significant presence in the sample of websites classified as 'non-professional'. Among them, there are variety websites and websites aimed at specific niches, such as community or religious audiences. There are also websites structured as news portals, which simulate journalistic formats and genre, but do not provide information on authorship, team or editorial guidelines. In other words, these websites emulate the credibility of the news media [Tandoc Jr., 2019], but it is not possible to assign responsibility for their content. Without information on authorship or clear editorial criteria, it becomes more difficult to guarantee the accuracy of the content. It is worth noting that these websites' contents are among those with the highest engagement in the context of the pandemic, whereby the reliability of the sources is essential to promote a public debate that contributes to facing the crisis.

\footnotetext{
${ }^{14}$ Available at https: / / plantaoaovivo.com.br/enquete-voce-acha-que-o-lula-se-sairia-melhor-quebolsonaro-no-combate-ao-coronavirus-no-brasil/. Accessed: 15 April 2020.

${ }^{15}$ Available at https: / / plantaoaovivo.com.br/enquete-voce-e-a-favor-da-libertacao-de-presospara-evitar-epidemia-de-coronavirus-nas-prisoes-vote-aqui/. Accessed: 15 April 2020.

${ }^{16}$ Available at https:/ / noticias.uol.com.br/colunas/tales-faria/2020/03/16/bolsonaro-estaconvencido-de-que-coronavirus-e-plano-do-governo-chines.htm. Accessed: 15 April 2020.
} 
In this sense, it is imperative to highlight that, in our corpus, there were no institutional websites linked to institutions in the scientific and health fields, such as universities, research centres and agencies for the promotion of research. In previous work on the public debate about vaccines on social networks, these websites already had a low presence [Massarani, Leal and Waltz, 2020]. It seems that websites directly related to the areas of S\&T do not appear among the sources that guided the public debate of higher engagement about COVID-19 on social networks. In a context of a pandemic that demonstrates the significance of the reliability of sources in publishing scientific information [Chan et al., 2020], these results reinforce the importance of considering science and health communication strategies that take into account the dynamics of engagement on networks.

Final considerations
Our analysis indicates that, among the most engaging content about COVID-19 in the Brazilian context at the beginning of its epidemic, verified information published by 'professional' sources - more specifically, 'journalistic' — was predominantly present. The importance of journalism is confirmed as a fundamental field for science communication, especially in times of crisis. However, $13.5 \%$ of the content was identified as 'mis/disinformation', which, even though it may be attributable to errors in verification and interpretation, reinforces the importance of assessing the quality and reliability of the information circulating on the network.

In addition, it is worth highlighting that, even in smaller numbers, this content received higher average engagement than verified information. This may point out that 'mis/disinformation' could have greater visibility and capillary action on social networks. The mis/disinformation was mainly present in the form of false connections, that is, headlines that attract attention from readers and that are not confirmed when reading the text. This is particularly critical in a digital environment where content is often shared and commented on without its full reading. In addition, the infodemic generated by COVID-19 makes it more difficult to assess the reliability of the information.

In this sense, it is essential to highlight the non-occurrence of websites linked to research institutions, universities and other organisations in the area of science and technology and health. This research data shows that content produced by these institutions was not among the 100 most engaging contents in Brazilian public debates on COVID-19 in March 2020 on the analysed social networks. These results suggest that the dynamics of social network engagement need to be taken into account in science communication strategies in the country, especially in the context of the pandemic, when the demand for reliable sources is fundamental.

This study shows that digital social networks have become an important space for public debate about the pandemic, especially when we consider that communication technologies acquire an even greater role among the population due to social distancing. Therefore, strategies to combat infodemic and to promote accurate information in science and health must take into account the challenges posed by this environment.

Translated by Sabina Brusemini 
Ahmed, W., Bath, P. A., Sbaffi, L. and Demartini, G. (2019). 'Novel insights into views towards H1N1 during the 2009 pandemic: a thematic analysis of Twitter data'. Health Information $\mathcal{E}$ Libraries Journal 36 (1), pp. 60-72. https://doi.org/10.1111/hir.12247.

Allcott, H. and Gentzkow, M. (2017). 'Social media and fake news in the 2016 election'. Journal of Economic Perspectives 31 (2), pp. 211-236. https://doi.org/10.1257/jep.31.2.211.

Allcott, H., Gentzkow, M. and Yu, C. (2019). 'Trends in the diffusion of misinformation on social media'. Research $\mathcal{E}$ Politics 6 (2), pp. 1-8. https://doi.org/10.1177/2053168019848554.

Alsyouf, M., Stokes, P., Hur, D., Amasyali, A., Ruckle, H. and Hu, B. (2019). “Fake News' in urology: evaluating the accuracy of articles shared on social media in genitourinary malignancies'. BJU International 124 (4), pp. 701-706. https://doi.org/10.1111/bju.14787.

Araujo, M. B. and Naimi, B. (2020). 'Spread of SARS-CoV-2 Coronavirus likely to be constrained by climate'. MedRxiv. https://doi.org/10.1101/2020.03.12.20034728.

Barberia, L. G. and Gómez, E. J. (2020). 'Political and institutional perils of Brazil's COVID-19 crisis'. The Lancet 396 (10248), pp. 367-368. https://doi.org/10.1016/s0140-6736(20)31681-0.

Bastos, P. N. (2020). ‘Dialética do engajamento: uma contribuição crítica ao conceito'. [Dialectics of engagement: a critical contribution to the concept]. MATRIZes 14 (1), pp. 193-220. https://doi.org/10.11606/issn.1982-8160.v14i1p193-220.

Bernhardt, J. M. (2004). 'Communication at the core of effective public health'. American Journal of Public Health 94 (12), pp. 2051-2053. https://doi.org/10.2105/ajph.94.12.2051.

Brennen, J. S., Simon, F., Howard, P. and Nielsen, R. K. (7th April 2020). 'Types, sources and claims of COVID-19 misinformation'. Reuters Institute for the Study of Journalism. URL: https://reutersinstitute. politics . ox. ac . uk/types-sou rces-and-claims-covid-19-misinformation.

Bucchi, M. (2008). ‘Of deficits, deviations and dialogues: theories of public communication of science'. In: Handbook of Public Communication of Science and Technology. Ed. by M. Bucchi and B. Trench. London, U.K. and New York, U.S.A.: Routledge, pp. 57-76.

Bueno, W. C. (2009). 'Jornalismo científico: revisitando o conceito'. In: Jornalismo científico e desenvolvimento sustentável. Ed. by C. Victor, G. Caldas and S. Bortoliero. São Paulo, Brazil: All Print, pp. 157-178. 
Candido, D. S., Claro, I. M., de Jesus, J. G., Souza, W. M., Moreira, F. R. R., Dellicour, S., Mellan, T. A., du Plessis, L., Pereira, R. H. M., Sales, F. C. S., Manuli, E. R., Thézé, J., Almeida, L., Menezes, M. T., Voloch, C. M., Fumagalli, M. J., Coletti, T. M., da Silva, C. A. M., Ramundo, M. S., Amorim, M. R., Hoeltgebaum, H. H., Mishra, S., Gill, M. S., Carvalho, L. M., Buss, L. F., Prete, C. A., Ashworth, J., Nakaya, H. I., Peixoto, P. S., Brady, O. J., Nicholls, S. M., Tanuri, A., Rossi, Á. D., Braga, C. K. V., Gerber, A. L., C. Guimarães, A. P. de, Gaburo, N., Alencar, C. S., Ferreira, A. C. S., Lima, C. X., Levi, J. E., Granato, C., Ferreira, G. M., Francisco, R. S., Granja, F., Garcia, M. T., Moretti, M. L., Perroud, M. W., Castiñeiras, T. M. P. P., Lazari, C. S., Hill, S. C., de Souza Santos, A. A., Simeoni, C. L., Forato, J., Sposito, A. C., Schreiber, A. Z., Santos, M. N. N., de Sá, C. Z., Souza, R. P., Resende-Moreira, L. C., Teixeira, M. M., Hubner, J., Leme, P. A. F., Moreira, R. G., Nogueira, M. L., Ferguson, N. M., Costa, S. F., Proenca-Modena, J. L., Vasconcelos, A. T. R., Bhatt, S., Lemey, P., Wu, C.-H., Rambaut, A., Loman, N. J., Aguiar, R. S., Pybus, O. G., Sabino, E. C. and Faria, N. R. (2020). 'Evolution and epidemic spread of SARS-CoV-2 in Brazil'. Science 369 (6508), pp. 1255-1260. https://doi.org/10.1126/science.abd2161.

Castelfranchi, Y., Vilela, E. M., de Lima, L. B., de Castro Moreira, I. and Massarani, L. (2013). 'As opiniões dos brasileiros sobre ciência e tecnologia: o paradoxo da relação entre informação e atitudes'. História, Ciências, Saúde-Manguinhos 20 (Suppl. 1), pp. 1163-1183. https://doi.org/10.1590/s0104-59702013000400005.

Chan, A. K. M., Nickson, C. P., Rudolph, J. W., Lee, A. and Joynt, G. M. (2020). 'Social media for rapid knowledge dissemination: early experience from the COVID-19 pandemic'. Anaesthesia, pp. 1-4. https://doi.org/10.1111/anae.15057.

Chew, C. and Eysenbach, G. (2010). 'Pandemics in the age of Twitter: content analysis of Tweets during the 2009 H1N1 outbreak'. PLoS ONE 5 (11), e14118. https://doi.org/10.1371/journal.pone.0014118.

Chou, W.-Y. S., Hunt, Y. M., Beckjord, E. B., Moser, R. P. and Hesse, B. W. (2009). 'Social media use in the United States: implications for health communication'. Journal of Medical Internet Research 11 (4), e48. https://doi.org/10.2196/jmir.1249.

Cinelli, M., Quattrociocchi, W., Galeazzi, A., Valensise, C. M., Brugnoli, E., Schmidt, A. L., Zola, P., Zollo, F. and Scala, A. (2020). 'The COVID-19 social media infodemic'. Scientific Reports 10 (1), 16598. https://doi.org/10.1038/s41598-020-73510-5. arXiv: 2003.05004.

Davies, S. R. and Horst, M. (2016). Science Communication: culture, identity and citizenship. London, New York and Shanghai: Palgrave Macmillan. https://doi.org/10.1057/978-1-137-50366-4.

Fuchs, C. (2020). 'Everyday life and everyday communication in coronavirus capitalism'. tripleC: Communication, Capitalism \& Critique 18 (1), pp. 375-398. https://doi.org/10.31269/triplec.v18i1.1167.

Gallotti, R., Valle, F., Castaldo, N., Sacco, P. and Domenico, M. D. (2020). 'Assessing the risks of 'infodemics' in response to COVID-19 epidemics'. arXiv: 2004.03997.

Glik, D. C. (2007). 'Risk communication for public health emergencies'. Annual Review of Public Health 28 (1), pp. 33-54.

https://doi.org/10.1146/annurev . publhealth.28.021406.144123. 
Graves, L. and Cherubini, F. (2016). The rise of fact-checking sites in Europe. Oxford, U.K.: Reuters Institute/University of Oxford. URL: https ://reutersin stitute.politics.ox.ac.uk/sites/default/files/research/files/The\%252 ORise $\% 2520$ of $\% 2520$ Fact-Checking $\% 2520$ Sites $\% 2520$ in $\% 2520$ Europe.pdf.

Graves, L., Nyhan, B. and Reifler, J. (2016). 'Understanding innovations in journalistic practice: a field experiment examining motivations for fact-checking'. Journal of Communication 66 (1), pp. 102-138. https://doi.org/10.1111/jcom.12198.

Hagen, L., Keller, T., Neely, S., DePaula, N. and Robert-Cooperman, C. (2018). 'Crisis communications in the age of social media: a network analysis of Zika-related tweets'. Social Science Computer Review 36 (5), pp. 523-541. https://doi.org/10.1177/0894439317721985.

Hao, K. and Basu, T. (12th February 2020). 'The coronavirus is the first true social-media "infodemic". MIT Technology Review.

URL: https://www. technologyreview.com/2020/02/12/844851/the-coronavi rus-is-the-first-true-social-media-infodemic/.

Hine, C. (2015). Ethnography for the internet: embedded, embodied and everyday. London, U.K. and New York, NY, U.S.A.: Bloomsbury.

Instituto Brasileiro de Geografia e Estatística (2018). Acesso à internet e à televisão e posse de telefone. Pesquisa Nacional por Amostra de Domicílios Contínua Pnad Contínua. URL: https://www.ibge.gov.br/estatisticas/sociais/popu lacao/17270-pnad-continua. html?edicao=27138et=sobre.

Joshi, A., Sparks, R., McHugh, J., Karimi, S., Paris, C. and MacIntyre, C. R. (2020). 'Harnessing tweets for early detection of an acute disease event'. Epidemiology 31 (1), pp. 90-97. https://doi.org/10.1097/ede.0000000000001133.

Kahan, D. M., Scheufele, D. A. and Jamieson, K. H. (2017). 'Introduction: why science communication?' In: The Oxford handbook of the science of science communication. Ed. by K. H. Jamieson, D. M. Kahan and D. A. Scheufele. Oxford, U.K.: Oxford University Press, pp. 1-14. https://doi.org/10.1093/oxfordhb/9780190497620.013.1.

Kaplan, A. M. and Haenlein, M. (2010). 'Users of the world, unite! The challenges and opportunities of Social Media'. Business Horizons 53 (1), pp. 59-68. https://doi.org/10.1016/j.bushor.2009.09.003.

Latour, B. (2005). Reassembling the social: An introduction to actor-network-theory. Oxford, U.K.: Oxford University Press.

Massarani, L. (2012). 'Comunicação da ciência e apropriação social da ciência: algumas reflexões sobre o caso do Brasil'. Revista Uni-pluriversidad 12 (3), pp. 92-100.

URL: https://revistas.udea.edu.co/index.php/unip/article/view/15161.

Massarani, L. and De Castro Moreira, I. (2016). 'Science communication in Brazil: A historical review and considerations about the current situation'. Anais da Academia Brasileira de Ciências 88 (3), pp. 1577-1595. https://doi.org/10.1590/0001-3765201620150338.

Massarani, L., Leal, T. and Waltz, I. (2020). 'O debate sobre vacinas em redes sociais: uma análise exploratória dos links com maior engajamento'. [The debate on vaccines in social networks: an exploratory analysis of links with the heaviest traffic]. Cadernos de Saúde Pública 36 (Suppl. 2), pp. 1-13. https://doi.org/10.1590/0102-311x00148319. 
Mendonça, A. P. B. and Neto, A. P. (2015). ‘Critérios de avaliação da qualidade da informação em sites de saúde: uma proposta'. Revista Eletrônica de Comunicação, Informação e Inovação em Saúde 9 (1), pp. 1-15.

https://doi.org/10.29397/reciis.v9i1.930.

Moorhead, S. A., Hazlett, D. E., Harrison, L., Carroll, J. K., Irwin, A. and Hoving, C. (2013). 'A new dimension of health care: systematic review of the uses, benefits and limitations of social media for health communication'. Journal of Medical Internet Research 15 (4), e85. https://doi .org/10.2196/jmir. 1933.

Newman, N., Fletcher, R., Schulz, A., Andi, S. and Nielsen, R. K. (2020). Reuters Institute digital news report 2020. London, U.K.: Reuters Institute/University of Oxford.

Posetti, J. and Bontcheva, K. (2020). Disinfodemic: deciphering COVID-19 disinformation. Policy brief 1 . Paris, France: UNESCO.

URL: https://en.unesco.org/sites/default/files/disinfodemic_decipher ing_covid19_disinformation.pdf.

Pulido, C. M., Villarejo-Carballido, B., Redondo-Sama, G. and Gómez, A. (2020). 'COVID-19 infodemic: more retweets for science-based information on coronavirus than for false information'. International Sociology 35 (4), pp. 377-392. https://doi.org/10.1177/0268580920914755.

Recuero, R., Zago, G. and Soares, F. (2019). 'Using social network analysis and social capital to identify user roles on polarized political conversations on Twitter'. Social Media + Society 5 (2), pp. 1-18. https://doi.org/10.1177/2056305119848745.

Salathé, M. (2018). 'Digital epidemiology: what is it and where is it going?' Life Sciences, Society and Policy 14 (1), pp. 1-5. https://doi.org/10.1186/s40504-017-0065-7.

Salaverría, R., Buslón, N., López-Pan, F., León, B., López-Goñi, I. and Erviti, M.-C. (2020). 'Desinformación en tiempos de pandemia: tipología de los bulos sobre la COVID-19'. El Profesional de la Información 29 (3). https://doi.org/10.3145/epi.2020.may.15.

Schiavo, R. (2007). Health communication: from theory to practice. San Francisco, CA, U.S.A.: Jossey-Bass.

Sharma, M., Yadav, K., Yadav, N. and Ferdinand, K. C. (2017). 'Zika virus pandemic - analysis of Facebook as a social media health information platform'. American Journal of Infection Control 45 (3), pp. 301-302. https://doi.org/10.1016/j.ajic.2016.08.022.

Shoureshi, P. S., Lee, W., Kobashi, K. C. and Sajadi, K. P. (2020). 'Media coverage of the 2019 United States Food and Drug Administration ordered withdrawal of vaginal mesh products for pelvic organ prolapse'. International Urogynecology Journal, pp. 1-5. https://doi.org/10.1007/s00192-020-04401-6.

Silva Medeiros, F. N. da and Massarani, L. (2011). 'A cobertura da gripe A(H1N1) 2009 pelo Fantástico'. Intercom: Revista Brasileira de Ciências da Comunicação 34 (1), pp. 41-59. https://doi.org/10.1590/s1809-58442011000100003.

Silva, L. M., Luce, B. and Silva Filho, R. C. (2017). 'Avaliação de critérios para fontes de informações na área da saúde no contexto da pós-verdade'. In: Anais do IV Encontro Regional dos Estudantes de Biblioteconomia, Documentação, Ciência e Gestão da Informação. Porto Alegre, Brazil: UFRGS. URL: https://lume .ufrgs . br/bits tream/handle/10183/157720/001021282.pdf.

Smith, B. G. and Gallicano, T. D. (2015). 'Terms of engagement: analyzing public engagement with organizations through social media'. Computers in Human Behavior 53, pp. 82-90. https://doi.org/10.1016/j.chb.2015.05.060. 
Sommariva, S., Vamos, C., Mantzarlis, A., Đào, L. U.-L. and Tyson, D. M. (2018). 'Spreading the (fake) news: exploring health messages on social media and the implications for health professionals using a case study'. American Journal of Health Education 49 (4), pp. 246-255. https://doi.org/10.1080/19325037.2018.1473178.

Tandoc Jr., E. C. (2019). 'The facts of fake news: a research review'. Sociology Compass 13 (9), pp. 1-9. https://doi.org/10.1111/soc4.12724.

The Lancet (2020). 'COVID-19 in Brazil: "so what?"' The Lancet 395 (10235), p. 1461. https://doi.org/10.1016/s0140-6736(20)31095-3.

Trench, B. and Bucchi, M. (2010). 'Science communication, an emerging discipline'. JCOM 09 (03), C03. https://doi .org/10.22323/2.09030303.

Wardle, C. and Derakhshan, H. (2017). Information disorder: toward an interdisciplinary framework for research and policymaking. Strasbourg, France: Council of Europe. URL: https://rm. coe.int/information-disorder-towardan-interdisciplinary-framework-for-researc/168076277c.

Waszak, P. M., Kasprzycka-Waszak, W. and Kubanek, A. (2018). 'The spread of medical fake news in social media — the pilot quantitative study'. Health Policy and Technology 7 (2), pp. 115-118. https://doi.org/10.1016/j.hlpt.2018.03.002.

World Health Organization (2018). Managing epidemics: key facts about major deadly diseases. Geneva, Switzerland: World Health Organization. URL: https://apps . who.int/iris/handle/10665/272442.

- (2020). 'Infodemic management: a key component of the COVID-19 global response'. Weekly Epidemiological Record 95 (16), pp. 145-148. URL: https: //apps . who . int/iris/handle/10665/331775.

Zarocostas, J. (2020). 'How to fight an infodemic'. The Lancet 395 (10225), p. 676. https://doi.org/10.1016/s0140-6736(20)30461-x.

Luisa Massarani is a Brazilian science communicator, who carries out both practical and research activities in the field. She is the coordinator of the master on Science Communication at Oswaldo Cruz House/Fiocruz (Brazil), of the National Institute of Public Communication of Science and Technology (INCT-CPCT) and for Latin American of SciDev.Net. Recipient of the Mercosur Award for Science and Technology (2014), the José Reis Science Communication Award, second place in Literature Jabuti Award (2017), and the Woman Press Award in the category Academic Contribution to Journalism (2020). E-mail: luisa.massarani6@gmail.com.

Igor Waltz is a researcher at the National Institute of Public Communication of Science and Technology (INCT-CPCT) with a scholarship awarded by the Brazilian National Council for Scientific and Technological Development (CNPq). PhD (2019) and Master (2015) in Communication and Culture awarded by the School of Communication at the Federal University of Rio de Janeiro (UFRJ) in the research field of Media and Sociocultural Mediations. He graduated in Social Communication/Journalism from the Federal University of Rio de Janeiro (UFRJ) in 2010. Member of the research group Media, Audiovisual Journalism and Education (MJAE). E-mail: igor.waltz2@gmail.com. 
Tatiane Leal is a postdoctoral researcher at the National Institute of Public Communication of Science and Technology (INCT-CPCT) with a scholarship awarded by the Carlos Chagas Filho Research Support Foundation (FAPERJ). PhD and Master in Communication and Culture awarded by the Federal University of Rio de Janeiro (UFRJ) in the research field of Media and Sociocultural Mediations. Vice-Coordinator of the Centre for Media Studies, Emotions and Sociability (NEMES). E-mail: tatianeclc@gmail.com.

How to cite

Massarani, L., Waltz, I. and Leal, T. (2020). 'COVID-19 in Brazil: an analysis about the consumption of information on social networks'. JCOM 19 (07), A07. https://doi.org/10.22323/2.19070207. 